\section{How to lubricate the gears of Texas higher education}

\section{Austin}

Although the major centres of higher education in the United States are still on the country's two coasts, Texas universities have been making steady progress towards national prominence. When oil flowed freely, universities in Texas enjoyed the boom. Now, with the state's oilbased economy depressed, higher education is struggling.

When a special session of the legislature last year had to cut $\$ 512$ million from the state's $\$ 19,000$ million budget, $\$ 200$ million came from funds for higher education. But supporters of higher education are preparing to fight as the next round of the budget debate gets under way to restore funds, allowing Texan universities to continue their improvement.

Ammunition for the fight comes from a report released last week by the select committee on higher education. Recognizing that the state's financial difficulties threaten earlier gains in higher education, the state legislature in 1985 created the select committee to consider the problem. After 15 months, including some 30 allday sessions, the committee's recommendations encompass a variety of issues ranging from faculty salaries to requirements for undergraduate degrees and state support for basic research at universities.

One recommendation that appears to have strong backing is state support for university research. In 1985, the legislature created the Texas Advanced Technology Research Program(TATRP), providing $\$ 35$ million for competitive research grants for scientists in the state's public universities. Grants were awarded to five areas, based on a National Academy of Sciences report which identified

\section{New Wellcome unit London}

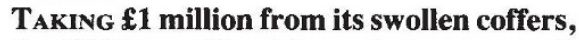
the Wellcome Trust has set up a new unit within the University of Glasgow. The Wellcome Unit of Molecular Parasitology, directed by Dr Andrew Tait, is to concentrate on molecular and genetic investigations of the basic biology of parasites.

The unit, which is guaranteed for five years, is the first to be funded by Wellcome Trust since it announced that it would be looking for suitable long-term university projects to fund with the extra income derived from its sale of 25 per cent of its (until then wholly-owned) shares in Wellcome plc, the pharmaceutical group whose share have doubled in value in the last month largely because of the anticipated sales of Retrovir (AZT) as a treatment for AIDS. Peter Newmark promising research areas.

Norman Hackerman, formerly president of the University of Texas at Austin and Rice University and a member of the select committee, says TATRP gave the government of Texas a chance to "get its feet wet" in research support based on

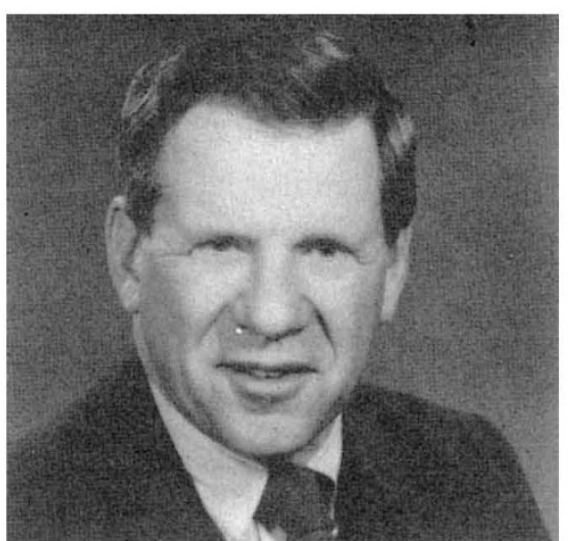

William Hobby, champion of higher education peer review. Hackerman headed the committee's task force on research, which has recommended continuing and expanding the TATRP programme. As well as supporting technology, the report urges the state to award between $\$ 20$ and $\$ 40$ million - approximately 10 per cent of the amount from the federal government for basic research at universities. The report also recommends that institutions should receive half of the indirect cost reimbursement accompanying federal grants.

But peer-reviewed distribution of funds presents political problems. The panel chosen to divide TATRP funds would have given 90 per cent of the money to researchers from the University of Texas at Austin and Texas A\&M University at College Station. But legislators, jealous of their already high status, prevented them from receiving more than two-thirds of the TATRP funds.

Admiral Bobby Inman, formerly president of the Texas-based Microelectronics and Computer Technology Corporation and originator of the TATRP concept, believes a form of intellectual elitism is ultimately good for the state. In hard economic times, it makes good sense to put resources where they will do the most good, says Inman. If that means just a handful of institutions win grants, so be it.

Resolving regional differences occupied a large portion of the select committee's energy. Economic necessity seemed to require closing some institutions opened during more prosperous times. But closing a university is "harder than moving a cemetery", says Texas commissioner of higher education Kenneth Ashworth.
Many communities appeared before the board to plead their local university's case. One school even rented a hot-air balloon to fly over Austin to protest at its potential demise. In the end, the committee opted to recommend retaining all 37 universities, 49 community colleges, 4 technical institutes and 8 medical and health-related institutions. Instead of closing universities, the committee recommends that some institutions abandon their graduate programmes and stick to undergraduate education. But even that will be opposed.

Ashworth says this is a time for higher education to put the brakes on expansion, and to find ways to guarantee support for existing institutions. He is the first to point out that the cuts in the Texas education budget have had a serious and detrimental impact on faculty recruiting. Texas faculty members earned $10 \cdot 2$ per cent less than the average paid to faculty members in the ten largest states a year ago (Texas is third largest). That figure is expected to reach 14.4 per cent in the current academic year. Unless the new state budget provides more salary funds, Texas universities will have tremendous problems recruiting and retaining staff, says Ashworth.

Hans Mark, chancellor of the University of Texas system, agrees with Ashworth that raising salaries is critically important to maintain the health of higher education. But he "emphatically disagrees" with Ashworth's suggestion that the time is not right for expansion. Mark is actively seeking both federal and private funds to help establish new facilities and attract top talent. Mark believes there is reason for optimism about state revenues. He suggests that if oil prices reach $\$ 20$ per barrel, and certain short-term increases in sales tax are extended, possible budget shortfalls will not materialize.

A powerful champion of higher education in Texas is Lieutenant Governor William Hobby. A member of the select committee, Hobby has been lieutenant governor since 1972 and is well versed in the intricacies of Texas politics. Hobby talks with pride of the state's academic achievements but bemoans the fact that Texas has less than one-tenth the number of members of the National Academy of Science that California has. Hobby has worked hard to persuade the state's congress that a strong educational system is needed to restore Texas to economic health.

But there is a danger that selling education for its economic benefits may backfire if the economy does not improve. Larry Temple, an Austin lawyer who chaired the select committee, says it is hard to get politicians to take a 20 or 30 year perspective on the benefits of education. But he likes to remind people that, no matter what size the Texan oil reserves may be, it will take educated minds to find them.

Joseph Palca 